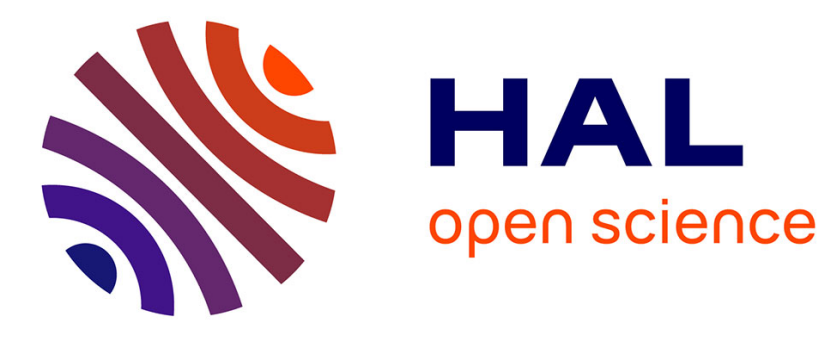

\title{
L19. Lymphoid neogenesis in vascular chronic inflammation.
}

\author{
Antonino Nicoletti, Jamila Khallou-Laschet, Kevin Guedj, Marc Clement, \\ Anh-Thu Gaston, Marion Morvan, Charles-Antoine Dutertre, Jean-Baptiste \\ Michel, Olivier Thaunat, Giuseppina Caligiuri
}

\section{To cite this version:}

Antonino Nicoletti, Jamila Khallou-Laschet, Kevin Guedj, Marc Clement, Anh-Thu Gaston, et al.. L19. Lymphoid neogenesis in vascular chronic inflammation.. La Presse medicale, 2013, 42 (4 Pt 2), pp.558-60. 10.1016/j.lpm.2013.01.018 . inserm-00805493

\section{HAL Id: inserm-00805493 https://www.hal.inserm.fr/inserm-00805493}

Submitted on 28 Mar 2013

HAL is a multi-disciplinary open access archive for the deposit and dissemination of scientific research documents, whether they are published or not. The documents may come from teaching and research institutions in France or abroad, or from public or private research centers.
L'archive ouverte pluridisciplinaire HAL, est destinée au dépôt et à la diffusion de documents scientifiques de niveau recherche, publiés ou non, émanant des établissements d'enseignement et de recherche français ou étrangers, des laboratoires publics ou privés. 


\section{Lymphoid neogenesis in vascular chronic inflammation}

Antonino Nicoletti ${ }^{1,2}$, Jamila Khallou-Laschet ${ }^{1,2}$, Kevin Guedj ${ }^{1,2}$, Marc Clement ${ }^{1,2}$, Anh-Thu Gaston ${ }^{1,2}$, Marion Morvan ${ }^{1,2}$, Charles-Antoine Dutertre ${ }^{1,2}$, Jean-Baptiste Michel $^{1,2}$, Olivier Thaunat ${ }^{3,4}$, Giuseppina Caligiuri ${ }^{1,2}$

1: Unité 698, Institut National de la Santé et de la Recherche Médicale, Hôpital Xavier Bichat, Paris, France.

2: UMRS698 Université Denis Diderot, Paris VII, Paris, France.

3: Hospices Civils de Lyon, Hôpital Edouard Herriot, Service de Transplantation Rénale et d'Immunologie Clinique, Lyon, France.

4: Université de Lyon, Lyon, France.

Address correspondence to:

Antonino Nicoletti, PhD

INSERM UMRS698 GH Bichat-Claude Bernard, 46 rue Henri Huchard, 75877

PARIS Cedex 18 (France)

Tel: +33 (0) 1402575 56; Fax: +33 (0) 140258602

E-mail: antonino.nicoletti@inserm.fr

Text word count: 1046 (w/o references) 
In contrast to secondary lymphoid organs (SLOs) that arise during development at predetermined locations, the formation of tertiary lymphoid organs (TLOs) can occur in adults at ectopic sites in any tissue in the context of persistent inflammatory disorders, such as autoimmune diseases, cancer, and organ transplantation(1-3). The molecular mechanisms underlying the organization of chronic inflammatory infiltrates into ectopic lymphoid tissue recapitulatesome of those involved in lymphoid organogenesisduring development $(4,5)$ and hence this process hasbeen referred to as lymphoid neogenesis. Beyond anatomical similarities with SLOs, ectopic lymphoid tissues are fully functional and support the development of local adaptive immune responses, including the priming of naive lymphocytes (6), generation of memory subsets, and germinal center reactions (clonal expansions, somatic hypermutations, immunoglobulin class switching and antibody production), which are suspected to contribute to the exacerbation ofchronic inflammatory diseases $(7,8)$.

\section{$1 /$ TLOs in rejected organs}

We have undertaken several studies in the context of alloimmunity and have demonstrated 1 / that the graft is not only the target of the alloimmune response but also a site where this response actually develops, so as to optimize the communication between the targeted tissue and the immune effectors(9), 2/ that TLOs provide survival signal to B-cells, allowing them to escape rituximab-induced apoptosis, thereby thwarting therapeutic efficiency (10), 3/ that anti-MHC humoral response is more intense and more diverse in TLOs [the abnormal activation of CD4+ $\mathrm{T}$ cells promotes the development of an exaggerated pathogenic immune humoral response in TLOs due to a defective immune regulation(11) and the intragraft microenvironment interferes with peripheral deletion of autoreactive immature B cells that, in turn, produce antibodies against intracellular autoantigens 
(12)], 4/ that intragraft humoral immune response appears uncoupled from the systemic response and that TLO formation recapitulate organogenesis of SLOs (13).

While these data demonstrate that chronic rejection isassociated with the development of lymphoid nodularinfiltrates within rejected organs, evidence for the involvement of these lymphoid structures in the rejection process came from a model of rat aortic interposition model where lymphoid nodular infiltrates was evidenced in the adventitia of the chronically rejected aorticgrafts (3). We could demonstrate that nodular lymphoidstructures were functional ectopic germinal centers thatparticipate in the rejection process of the grafted organ. In addition, this showed that the vascular stroma was sufficient to promote and support lymphoid neogenesis.

\section{2/ TLOs in atherothrombosis}

Interestingly, TLOs are also present in the context of atherothrombosis. Indeed, TLOs were detected in the adventitia of human atherosclerotic arteries as early as the 1950s(14), a process that has been recently revisited(15-18). We couldalso characterize adventitial lymphoid aggregates distributed all along the aortic segment in atherosclerosis-prone ApoE KO mice. These structures were defined as TLOs because they are composed of B cell follicles surrounded by T cells, a prototypic organization reported for ectopic germinal centers(4). $\lg M$ and $\lg D$ staining revealed the presence of two subsets of B cells with different maturation states. Moreover, these TLOs included blood vessels, lymphatic networks, and FRC-like cells, suggesting that these aggregates are proper structures to induce and maintain local immune responses. These adventitial blood and lymphatic networks are essential for the recruitment and drainage of immune effectors(19-22). Interestingly, the TLOs were polarized towards the media, suggesting that effectors inside the aortic wall may be involved in the lymphangiogenesis and angiogenesis associated with the 
formation of adventitial TLOs. In this respect, it is important to note that human VSMCs are able to trigger intramural angiogenesis through the production of VEGF$A(23)$.

\section{3/ Mechanisms of lymphoid neogenesis in the aorta}

A detailed characterization of TLOs in ApoE KO mouse aortas showed that vascular smooth muscle cells (VSMCs) in the media express the chemokines CXCL13, CCL19, CCL21, and CXCL16, triggering the recruitment of leukocytes to the adventitia(16). This raised the question of the identity of the cellular and molecular factors that confer an organizer (LTo) potential upon VSMCs. We hypothesized that macrophages could act as Lymphoid Tissue inducer (LTi) cells in diseased arteries. Indeed, macrophages are key players in host defense and tissue homeostasis and are heterogeneous and plastic cells that can mount different programs of polarized activation according to microenvironmental cues (24). M1-polarized macrophages are considered as pro-inflammatory cells that produce high levels of effectors, such as the cytokine interleukin-1 $\beta$, while M2-polarized macrophages are rather reparative cells, promoting the synthesis of extracellular matrix components. In the context of advanced atheroma, plaque-infiltrated macrophages have an M1 pro-inflammatory profile(25, 26).

Our data suggest that M1 inflammatory macrophages are relevant LTi candidates because they express high LT- $\alpha$ and TNF- $\alpha$ levels. However, instead of acting through "classical" cell-cell interactions that characterize LTo induction, intimal macrophages assume an LTi role remotely, via soluble factors, thus endowing VSMCs with LTo functions. We further showed that the effect of M1 macrophages on VSMCs involved TNFR1/2 signaling and was LT $\beta R$-independent 
The results obtained in vitrowere corroborated by those collected in anin vivo aortic transposition model. Indeed, we demonstrated the presence of adventitial aortic TLOs in LTßR KO segments that had been transplanted into ApoE KO mice. Together, these findings demonstrate that, in the context of atherosclerosisassociated lymphoid neogenesis, LTßR signaling is dispensable.

To definitively validate these observations, we used collagen scaffolds seeded with VSMCs that had been stimulated ex vivo with M1 conditioned medium (CM) or with control media. These scaffolds were then implanted subcutaneously in mice. Three weeks after implantation, we found that scaffolds seeded with M1 CM-stimulated VSMCs contained lymphoid cell aggregates, which were not detected in scaffolds containing unstimulated VSMCs. The lymphoid cells that composed these aggregates were $\mathrm{CD}^{+} \mathrm{T}$ and $\mathrm{B} 220^{+} \mathrm{B}$ cells. SMA-positive VSMCs surrounding the aggregates expressed CCL19, CCL20, and CXCL16.

In summary, for the first time, our most recent data show that classical LTi cells might not be mandatory for the development of TLOs, a role that can be assumed by macrophages. Indeed, in the context of atherosclerosis, soluble mediators produced by intimal M1 macrophages activate medial VSMCs through their TNF receptors independently of LT $\beta R$ signaling. These findings support the hypothesis that radial hydraulic conductance conveys information from the intima toward the adventitia in the following manner: intimal macrophages transmit LTi-inducing signals to medial VSMCs, which, in turn, orchestrate chemoattraction and lymphoid neogenesis in the adventitia. 


\section{References}

1. Baddoura FK, Nasr IW, Wrobel B, Li Q, Ruddle NH, Lakkis FG. Lymphoid neogenesis in murine cardiac allografts undergoing chronic rejection. Am J Transplant. 2005;5(3):510-6. Epub 2005/02/15.

2. Kerjaschki D, Regele HM, Moosberger I, Nagy-Bojarski K, Watschinger B, Soleiman A, et al. Lymphatic neoangiogenesis in human kidney transplants is associated with immunologically active lymphocytic infiltrates. J Am Soc Nephrol. 2004;15(3):603-12. Epub 2004/02/24 .

3. Thaunat O, Field AC, Dai J, Louedec L, Patey N, Bloch MF, et al. Lymphoid neogenesis in chronic rejection: evidence for a local humoral alloimmune response. Proc Natl Acad Sci U S A. 2005;102(41):14723-8.

4. Drayton DL, Liao S, Mounzer RH, Ruddle NH. Lymphoid organ development: from ontogeny to neogenesis. Nat Immunol. 2006;7(4):344-53. Epub $2006 / 03 / 22$.

5. Kratz A, Campos-Neto A, Hanson MS, Ruddle NH. Chronic inflammation caused by lymphotoxin is lymphoid neogenesis. J Exp Med. 1996;183(4):146172. Epub 1996/04/01.

6. Nasr IW, Reel M, Oberbarnscheidt MH, Mounzer RH, Baddoura FK, Ruddle $\mathrm{NH}$, et al. Tertiary lymphoid tissues generate effector and memory $\mathrm{T}$ cells that lead to allograft rejection. Am J Transplant. 2007;7(5):1071-9. Epub 2007/03/16.

7. Armengol MP, Juan M, Lucas-Martin A, Fernandez-Figueras MT, Jaraquemada D, Gallart T, et al. Thyroid autoimmune disease: demonstration of thyroid antigen-specific $B$ cells and recombination-activating gene expression in 
chemokine-containing active intrathyroidal germinal centers. Am J Pathol. 2001;159(3):861-73. Epub 2001/09/11 .

8. Schroder AE, Greiner A, Seyfert C, Berek C. Differentiation of B cells in the nonlymphoid tissue of the synovial membrane of patients with rheumatoid arthritis. Proc Natl Acad Sci U S A. 1996;93(1):221-5. Epub 1996/01/09.

9. Thaunat O, Louedec L, Dai J, Bellier F, Groyer E, Delignat S, et al. Direct and indirect effects of alloantibodies link neointimal and medial remodeling in graft arteriosclerosis. Arterioscler Thromb Vasc Biol. 2006;26(10):2359-65.

10. Thaunat O, Patey N, Gautreau C, Lechaton S, Fremeaux-Bacchi V, DieuNosjean MC, et al. B cell survival in intragraft tertiary lymphoid organs after rituximab therapy. Transplantation. 2008;85(11):1648-53. Epub 2008/06/14.

11. Thaunat O, Graff-Dubois S, Brouard S, Gautreau C, Varthaman A, Fabien N, et al. Immune responses elicited in tertiary lymphoid tissues display distinctive features. PLoS ONE. 2010;5(6):e11398. Epub 2010/07/09.

12. Thaunat O, Graff-Dubois S, Fabien N, Duthey A, Attuil-Audenis V, Nicoletti A, et al. A stepwise breakdown of B-cell tolerance occurs within renal allografts during chronic rejection. Kidney Int. 2012;81(2):207-19. Epub 2011/09/23.

13. Thaunat O, Patey N, Caligiuri G, Gautreau C, Mamani-Matsuda M, Mekki Y, et al. Chronic rejection triggers the development of an aggressive intragraft immune response through recapitulation of lymphoid organogenesis. $\mathrm{J}$ Immunol. 2010;185(1):717-28. Epub 2010/06/08.

14. Saphir O, Gore I. Evidence for an inflammatory basis of coronary arteriosclerosis in the young. Arch Pathol. 1950;49:418-26. 
15. Houtkamp MA, de Boer OJ, van der Loos CM, van der Wal AC, Becker AE. Adventitial infiltrates associated with advanced atherosclerotic plaques: structural organization suggests generation of local humoral immune responses. J Pathol. 2001;193(2):263-9. Epub 2001/02/17.

16. Grabner R, Lotzer K, Dopping S, Hildner M, Radke D, Beer M, et al. Lymphotoxin beta receptor signaling promotes tertiary lymphoid organogenesis in the aorta adventitia of aged ApoE-/- mice. J Exp Med. 2009;206(1):233-48. Epub 2009/01/14.

17. Moos MP, John N, Grabner R, Nossmann S, Gunther B, Vollandt R, et al. The lamina adventitia is the major site of immune cell accumulation in standard chow-fed apolipoprotein E-deficient mice. Arterioscler Thromb Vasc Biol. 2005;25(11):2386-91. Epub 2005/09/24.

18. Galkina E, Kadl A, Sanders J, Varughese D, Sarembock IJ, Ley K. Lymphocyte recruitment into the aortic wall before and during development of atherosclerosis is partially L-selectin dependent. J Exp Med. 2006;203(5):127382. Epub 2006/05/10.

19. Miyasaka M, Tanaka T. Lymphocyte trafficking across high endothelial venules: dogmas and enigmas. Nat Rev Immunol. 2004;4(5):360-70. Epub 2004/05/04.

20. Gallatin WM, Weissman IL, Butcher EC. A cell-surface molecule involved in organ-specific homing of lymphocytes. Nature. 1983;304(5921):30-4. Epub 1983/07/07.

21. Randolph GJ, Angeli V, Swartz MA. Dendritic-cell trafficking to lymph nodes through lymphatic vessels. Nat Rev Immunol. 2005;5(8):617-28. Epub 2005/08/02. 
22. Saeki H, Moore AM, Brown MJ, Hwang ST. Cutting edge: secondary lymphoidtissue chemokine (SLC) and CC chemokine receptor 7 (CCR7) participate in the emigration pathway of mature dendritic cells from the skin to regional lymph nodes. J Immunol. 1999;162(5):2472-5. Epub 1999/03/11.

23. Ho-Tin-Noe B, Le Dall J, Gomez D, Louedec L, Vranckx R, El-Bouchtaoui M, et al. Early atheroma-derived agonists of peroxisome proliferator-activated receptor-gamma trigger intramedial angiogenesis in a smooth muscle celldependent manner. Circ Res. 2011;109(9):1003-14. Epub 2011/09/03.

24. Biswas SK, Mantovani A. Macrophage plasticity and interaction with lymphocyte subsets: cancer as a paradigm. Nat Immunol. 2010;11(10):889-96. Epub 2010/09/22.

25. Bouhlel MA, Derudas B, Rigamonti E, Dievart R, Brozek J, Haulon S, et al. PPARgamma activation primes human monocytes into alternative M2 macrophages with anti-inflammatory properties. Cell Metab. 2007;6(2):137-43. Epub 2007/08/08.

26. Khallou-Laschet J, Varthaman A, Fornasa G, Compain C, Gaston AT, Clement M, et al. Macrophage plasticity in experimental atherosclerosis. PLoS One. 2010;5(1):e8852. Epub 2010/01/30. 